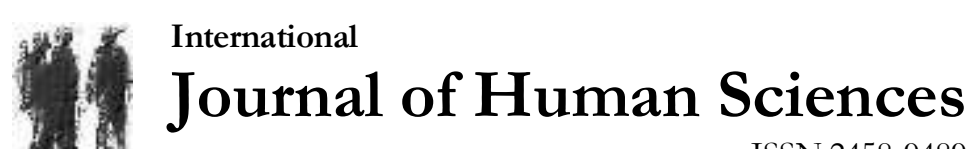 \\ ISSN:2458-9489
}

Volume 17 Issue 2 Year: 2020

\section{The effect on the psychological perception of exercise in female inmates ${ }^{1}$}

\author{
Elif Köse ${ }^{2}$ \\ Tennur Yerlisu Lapa ${ }^{3}$
}

\begin{abstract}
The aim of this study is to identify the psychological perception levels of the female inmates in Antalya Type-L Closed Penitentiary Institution and then to determine the effect of exercise on such perceptions. This is an experimental study with weak experimental design. Study sample consists of a total of 121 female prisoners; 32 in the experimental group, 43 in control group 1 and 46 in the control group 2. The data collection tools used in this study are Physical Activity Readiness Questionnaire for determining the physical activity levels of the individuals, Psychological Well-Being Scale, Beck Depression Inventory and State-Trait (STAI) Anxiety Inventory for identifying their psychological perceptions. T-Test, One-Way Analysis of Variance and LSD analysis -a Post-Hoc test- were used for data analysis. Consequently, the psychological perception levels of the female inmates before and after exercise were examined as per the groups they participated and the results revealed that there was no statistically significant difference among the depression, anxiety and psychological well-being levels of those inmates, who participated in the exercises. However, there was a significant increase on the depression levels in the control groups 1 and 2. In conclusion, it can be said that exercise plays an important role in protecting the psychological perceptions of the incarcerated individuals.
\end{abstract}

Keywords: Female Criminality, Inmate, Psychological Perceptions, Exercise.

\section{Introduction}

Physical activity is defined as the movements covering numerous activities in daily life that work the muscles and result in energy consumption (Soyuer \& Soyuer, 2008). Leisure time physical activity, on the other hand, is defined as a concept consisting of various daily activities with different intensity levels; it includes games and affect the heart and respiratory system (Güçlü, Sağlam, İnce, Savc1 \& Arrkan, 2008). Exercise, however; is the programmed version of physical activity. In other words, exercise refers to regular, systematic and constant physical activities performed voluntarily within a certain schedule, with the purpose of improving physical health (Kaya, Gedik, Bayram \& Bahçeci, 2011)

\footnotetext{
${ }^{1}$ This study is compiled from a Master Thesis.

2 Ph.D. Student, Akdeniz University, Health Sciences Institute, elifkose9@gmail.com; (iD) Orcid ID: 0000000254903534

3 Assoc. Prof. Dr., Akdeniz University, Sport Science of Faculty; tennur@akdeniz.edu.tr;

(iD) Orcid ID: 0000000286471473
} 
Köse, E., \& Yerlisu Lapa, T. (2020). The effect on the psychological perception of exercise in female inmates. Journal of Human Sciences, 17(2), 593-608. doi:10.14687/ihs.v17i2.5902

The importance of physical activity and exercise performed in leisure time increases every passing day. Gradually advancing technology brought along a sedentary lifestyle, which led to increased fat mass of the body. Hence, obesity became one the most important public health problems of the present-day (Kautiainen, Koivusilta, Lintonen, Virtanen \& Rimpelä, 2005). Additionally, many obesity-associated comorbidities such as coronary heart diseases, hypertension, diabetes etc. also present a gradual increase (Wolf \& Colditz, 1998). There is positive correlation between high level of physical activity and the ability to maintain a healthy life (Hills, Dengel \& Lubans, 2015). Moreover, exercise plays an important role in decreasing the risk of heart diseases that have a positive correlation with hypertension and other chronic diseases, losing weight, strengthening musculoskeletal system, reducing stress and blood pressure and improving the quality of life of the individuals (Fagard \& Cornelissen, 2007). In recent years, the positive effects of physical activity on the individuals started to draw the attention of researchers working in different fields and this prompted them to do more research on the physical activity and its benefits. Recent studies indicate that physical activity and exercise are beneficial not only physically but also cognitively, behaviorally and psychologically (Edwards, 2006; Kamijo, Hayashi, Sakai, Yahiro, Tanaka, \& Nishihira 2009; Stephan, Sutin, \& Terracciano, 2014). In the absence of physical activity, physiological health problems come to existence along with mental problems such as stress, depression and anxiety, whereas plasma beta-endorphin that elevates with physical activity and exercise changes the mental state of an individual (Callaghan, 2004: 480). Studies reveal that regular exercise slows down pulsation, lowers blood pressure, facilitates breathing and accordingly decreases the findings of stress and anxiety, prevents depression, improves sleep quality and contributes controlling one's emotions (Artal, Sherman \& Dinubile, 1998)

Depression is the state of psychological breakdown that can surface organically in the natural course of life and is believed to be associated with physical activity. It can be triggered by traumatic incidents and inheritance plays an important role as well as education and training. This psychological disorder is not always contained within the person experiencing it but can also be accompanied by hormonal disorders and environmental factors. Therefore, it is considered to be a danger that can affect those who are around the patients, equally. (Kendler, Karkowski \& Prescott, 1999). The prevalence of depression has increased so much in time that it is now referred to as "the common cold" of mental health (Bellack, Hersen \& Himmelhoc 1981). According to the data of Anxiety and Depression Association of America, anxiety and depression are the most common psychological disorders in the USA by affecting 18\% of the American population (Frank, Adkins, Thomas \& Dick, 2016). Although the importance of the rehabilitating effect of physical activity on health is already recognized, it is more and more recommended for also psychological disorders, in addition to physical ones and it plays a crucial role in the treatment of disorders such as depression and anxiety (Galper, Trivedi, Dunn \& Kampert, 2006). Studies demonstrate that physical activity elevates positive emotions such as life-satisfaction and wellness whereas alleviating negative moods like depression and anxiety (Wyshak, 2001). Some researchers consider physical activity as a preventive factor of negative moods such as depression and anxiety but psychological disorders like depression and anxiety can also develop as a result of the lack of physical activity (Engels, Currie, Lueck \& Wirth, 2002).

Anxiety is considered as another type of negative affect that the level of physical activity affects. The most widespread definition of anxiety is the state of uneasiness, where the individuals believe that any given situation will result in danger and misfortune for them. Anxiety is mostly defined as a reaction given to that internal stimulus that the individual feels inside, rational or irrational. The worry that the individual is feeling in the face of a non-objective danger is another characteristic of anxiety (Spielberger, Gorsuch \& Lushene, 1970). Sullivan, an anxiety researcher, asserts that anxiety results from a childhood deprived of love and affection that transforms into the feeling of insecurity in advanced ages. Sullivan also states that influential people that contribute to childrearing, mistaken attitudes of the parents towards their children, punishments given for educational purposes, inconsistent behaviors of the parents and early socialization memories of the 
Köse, E., \& Yerlisu Lapa, T. (2020). The effect on the psychological perception of exercise in female inmates. Journal of Human Sciences, 17(2), 593-608. doi:10.14687/ihs.v17i2.5902

child are also determinative of the development of anxiety later in life (Cit. Köknel, 2005: 135). Freud, on the other hand, claims that an individual meets anxiety during birth for the first time and a newborn is affected by many stimuli and the trauma experienced during that time is a deterministic factor on the anxiety level in upcoming years (Cit. Geçtan, 2005: 48). Anxiety is believed to be a serious mental health problem that must be treated, considering the fact that it, with a wide prevalence, is a triggering factor for some psychological disorders, which lowers the quality of life and labor capability of the individual (Spielberger et al., 1970). Reviewing the researches in the literature that focus on anxiety -a widely studied topic- and physical activity, it is safe to say that physical activity has positive effects on anxiety. Studies establish that exercise training decreases the effects of chronic anxiety and stress, while single-session exercise has a positive impact on state anxiety and it lowers the emotional and psychological reactions of stress (Ströhle, Feller, Onken, Godemann, Heinz \& Dimeo, 2014).

Psychological well-being is another concept for which exercise is considered to be a predictor. However, the definition and scope of the concept of psychological well-being have been interpreted differently, over time. While health was a concept of being disease-free before 1940s, today it is considered to be the state of intactness: physically, mentally and socially (Hefferon \& Boniwell, 2011: 7). Psychological well-being is defined as an in-depth concept that goes beyond how a person feels psychologically and it can be influenced by numerous factors (Ryff, 1989a: Ryff, 1989c). There are many definitions that refer to psychological well-being, since these factors bring along uncertainties as to both the definition and measurement of the concept and this situation prevents researchers from reaching a consensus decision-making on a definition of the concept of psychological well-being (Ryff \& Singer, 1996). The definition that all researchers agree upon at a minimum is that psychological well-being is a positive concept and psychological functionality must also be in a positive direction (Akın, 2008:). Ryff defines the characteristics of psychological wellbeing from the perspective of the individuals as follows: psychological well-being is being mindful about one's own life, developing healthy relationships with others and maintaining those relationships (Ryff \& Keyes, 1995). Besides, the person should have a positive sense of self, should be able to have self-integrity, should be responsive to the wishes and needs of others, should be an independent individual and should possess an enterprising personality (Keyes et al., 2002: 1008). According to Ryff, a person's relationship with others, autonomy, environmental interaction, personal development, life goals, self-acceptance, past experiences, physical health, economic conditions, received social support, positive \& negative effects and satisfaction with life can be shown as the factors that have an effect on one's psychological well-being (Ryff, 1989a; Ryff, 1989c). Among the studies that question the link between psychological well-being and exercise, the epidemiological ones that measure the effect of physical activity indicate that negative moods such as depression and anxiety decrease with increased physical activity level, whereas positive moods such as psychological well-being increase, concordantly (Windle, Hughes, Linck, Russell \& Woods, 2010). Moreover, studies also show that there is a positive correlation between a healthy state of mind and a healthy body. In other words, physical health is considered to be a predictor of mental health (Wyshak, 2011).

In the light of all this information, it is vitally important to turn exercise into a lifestyle for improving public health. Nowadays, increased quality of life is as much important as living long. Therefore, the importance of physical activity is scaling up every passing day for healthy aging and lowering the risk of age-related diseases (Hills et al., 2015: 370). Exercise is even more important for people leading a sedentary lifestyle so as to prevent the development of physiological and psychological problems. The role of exercise is undeniable for incarcerated individuals, who can be considered as a vulnerable group due to their sedentary lifestyle, economic insufficiency and solitude as well as other problems arising from a confined living. This is because incarcerated individuals are less inclined to exercise and more susceptible to problems relating to certain parameters (such as heart rate, systolic blood pressure, fatigue, physical pain, general state of health, mental health etc.) when compared to others who are not incarcerated as indicated by the limited number of studies in the literature. (Fazel, Hope, O’Donnell, Piper \& Jacoby, 2001; Kaya, Güler \& Çilli, 2004; Özalp \& Algün, 2013; Püllüm, 2011). 
Studies on inmates reveal that those who participate in regular exercise manifest decreased negative perception levels such as stress, anxiety, depression etc. (Amtmann, Evans \& Powers, 2001; Buckaloo, Krug \& Nelson, 2009; Leberman, 2007; Ozano, 2008; Wagner, McBride, \& Crouse, 1999); get physically stronger (Pérez-Moreno, Cámara-Sánchez, Tremblay, Riera-Rubio, Gil-Paisán \& Lucia, 2007); have lower levels of anger and rage (Wagner et al., 1999); have better sleep quality (Elger, 2009) and improved social relations \& self-confidence (Vaiciulis, Kavaliauskas \& Radisauskas, 2011). Other similar studies on inmates also indicate negative correlation between participation in exercise and some variables such as perception of boredom, engaging in fight and sexual assault etc. (Frey \& Delaney, 1996). The study of Başaran (2015) in the national literature concludes that a 12 -week exercise program has positive effects on the trait anxiety levels of the female inmates. However, the national literature contains limited number of studies uncovering the effect of exercise on the psychological perceptions of the incarcerated individuals. Therefore, the aim of this study is to ascertain the effect of exercise on the psychological perceptions of the female inmates.

$\mathrm{H} 1=$ Regular exercise has effect on the depression levels of the female inmates.

$\mathrm{H} 1=$ Regular exercise has effect on the trait anxiety levels of the female inmates.

$\mathrm{H} 1=$ Regular exercise has effect on the psychological well-being levels of the female inmates.

In this context, the aim of this study is first to identify the existing exercise and psychological perception levels of the female inmates and then to determine the effect of planned exercise performed in leisure time on the psychological perception of the female inmates.

\section{Method}

\section{Research Model}

This is an interventional study and it is designed as a weak experimental design among other experimental research types. Experimental designs are classified as true experimental designs, quasiexperimental designs and weak experimental designs (Fraenkel \& Wallen, 2006). Among these experimental research types, random assignment of people is only possible in the true experimental designs. While people are randomly assigned for the matched groups also in quasi-experimental designs, sample selection of weak experimental design differs from others with no random assignment of subjects or group matching. The biggest disadvantage of weak experimental design compared to other experimental designs is its inability to keep factors threatening internal validity under control (Büyüköztürk, Çakmak, Akgün, Karadeniz \& Demirel, 2014). However, in some cases it is not possible to assign people randomly or to match the individuals and groups. This lowers the ability to commentate on the causality (Fraenkel \& Wallen, 2006). Weak experimental designs divide into subgroups. The subgroup used in this study is the static-group pretest-posttest design. This subgroup is believed to be more convenient compared to other subgroups (one group pretestposttest design and static-group comparison design) as it has a control group and it provides information about the reference levels of the measured quality. It was not possible to assign female inmates in this study randomly since they were grouped as those who participated in exercises, those who participated in activities and those who did not agree to participate in any of them. This is because there was already a group of inmates who applied for various courses scheduled by the prison management for them to spend quality leisure time, but they were not able to engage in exercise due to unfavorable state of health. And another group was waiting to participate in the exercises instead of participating in leisure activities. Therefore, the individuals were asked to decide on the group they want to participate, on their own. As a result, this study was designed as a weak experimental design.

\section{Research Group}

The universe of the research consists of 202 female inmates incarcerated in Type-L Closed Penitentiary Institution in Antalya. Although all inmates were targeted to be included in the study, some of them were excluded due to different reasons (reluctance, transfer to open-prison or another 
Köse, E., \& Yerlisu Lapa, T. (2020). The effect on the psychological perception of exercise in female inmates. Journal of Human Sciences, 17(2), 593-608. doi:10.14687/ihs.v17i2.5902

prison etc.). Excluding the ones who did not take part in the study and the ones who dropped out later on, a total of 121 female inmates were studied including 34 detainees, 74 convicts and 13 appellants. G-Power analysis program was used for determining the sample size. A sample size of 34 people for each group was found sufficient with a confidence interval of $95 \%$ and the following values: $\alpha=.05, \beta=.20$ and $\mathrm{d}=.80$. A specific attention was paid to have at least 34 people in control group 1 and control group 2 in the experiment and the study was completed with a total of 121 people as follows: 32 people in the experimental group, 43 people in the control group 1 and 46 people in the control group 2 . The mean age of the study participants was calculated as the following: Mean $_{\text {age }}=32.66 \pm 10.024$. There are three groups of participants in our study: those who participated in exercises, those who did not participate in exercises but participated in activities organized by the prison management such as the training, seminars, courses, concerts etc. and those who did not participate in any of the activities organized by the prison management. The distribution of female inmates by the participation groups can be found in Table (1).

Table 1

Socio-Demographic Characteristics of the Female Inmates

\begin{tabular}{|c|c|c|c|}
\hline & & $\mathrm{n}$ & $\%$ \\
\hline \multirow{4}{*}{ Distribution of Participants by Groups } & Exercise Group & 32 & 26.4 \\
\hline & Activity Group & 43 & 35.5 \\
\hline & None & 46 & 38.0 \\
\hline & Total & 121 & 100.0 \\
\hline \multirow{6}{*}{ Distribution by Age } & 18 to 24 years & 25 & 20.8 \\
\hline & 25 to 34 years & 56 & 46.2 \\
\hline & 35 to 44 years & 20 & 16.6 \\
\hline & 45 to 54 years & 14 & 11.6 \\
\hline & 55 and more & 6 & 5.0 \\
\hline & Total & 121 & 100.0 \\
\hline \multirow{6}{*}{ Distribution by Educational Background } & Illiterate & 29 & 24.0 \\
\hline & Literate & 19 & 15.7 \\
\hline & Primary School & 35 & 28.9 \\
\hline & High School & 32 & 26.4 \\
\hline & University & 6 & 5.0 \\
\hline & Total & 121 & 100.0 \\
\hline \multirow{7}{*}{$\begin{array}{l}\text { Distribution by the Remaining Term of } \\
\text { Sentence }\end{array}$} & Less than 1 year & 29 & 23.9 \\
\hline & 1 to 4 years & 29 & 23.9 \\
\hline & 4 to 7 years & 15 & 12.2 \\
\hline & 7 to 10 years & 9 & 7.4 \\
\hline & 10 and more & 5 & 4.0 \\
\hline & Indeterminate & 34 & 28.6 \\
\hline & Total & 121 & 100.0 \\
\hline
\end{tabular}

The distribution percentages by the groups are as follows: (26.4\% for the exercise group), (35.5\% for the activity group) and (38\% for the non-participation group). The largest age group with the highest number of female inmates is 25 to 34 years, by $46.2 \%$. Looking at the educational background, which is considered to be one of the most determinant factors of crime, it is seen that the percentage of the illiterates is by $24.0 \%$, whereas the university graduates have the lowest percentage by $5 \%$. As for the remaining term of sentence of the inmates, $23.9 \%$ of the them has less than 1 year left to serve, $23.9 \%$ has 1 to 4 years, $12.2 \%$ has 4 to 7 years, $7.4 \%$ has 7 to 10 years and $4 \%$ has more than 10 years. 
Köse, E., \& Yerlisu Lapa, T. (2020). The effect on the psychological perception of exercise in female inmates. Journal of Human Sciences, 17(2), 593-608. doi:10.14687/ihs.v17i2.5902

\section{Data Collection Tools}

\section{Personal Information Form}

"Personal Information Form" was designed and used by the researcher for gathering information about the individuals that constitute the research group. Personal information form contains questions about the age, birthplace, educational status, marital status and socio-economic status of the inmates, including some questions about their remaining term of sentence and the prison conditions, which are believed to be a predictor of the research data.

\section{Physical Activity Readiness Questionnaire}

This questionnaire is a scale that contains seven questions to specify the state of readiness for physical activity. It aims to assess which one of the following stages people are at: precontemplation, contemplation, preparation and maintenance. This questionnaire is applied to discover the preexisting diseases of the individuals who wish to participate in the exercise program and the risk classification of their diseases (İnce \& Ebem, 2009).

\section{Beck Depression Inventory}

BDI was developed by Beck (1963) and it contains 21 questions. Its validity-reliability study was conducted by Hisli (1989) and the reliability coefficient was found .80. Under each of the 21 questions, there are 4 self-report phrases and each question is given one of the four scores $(0,1,2$, 3 ), which provides a four-point likert-scale type measurement. The lowest possible score that one can get from the inventory is 0 , whereas the highest is 63 and the cut-off score was calculated as 17 . The reliability coefficient of the pretest and posttest of Beck Depression Inventory was found .91 in the study.

\section{State-Trait (STAI) Anxiety Inventory}

This inventory was developed by Spielberger et al. (1970). Validity-reliability study and the Turkish adaptation of the Inventory were conducted by Oner and Le Compte (1985). The inventory has two sub-dimensions: state and trait. Considering the conditions of our study and the characteristics of the sample group, "Trait Anxiety" sub-dimension was used. The reliability coefficient of the STAI Anxiety Inventory was found .78 for its pretest and .81 for its posttest.

\section{Psychological Well-Being Scale}

Psychological Well-Being Scale was developed by Ryff (1989a) and adapted into Turkish culture by Akın (2008). The validity-reliability study of the Scale was conducted on 321 people. In this study, there are 6 sub-dimensions of the Psychological Well-Being Scale, developed by Ryff. Considering the characteristics of the sample group of the study, the sub-dimension of "Positive Relations with Others" was used so as to assess the ability to feel affection and intimacy for others and to build warm \& trusting relationships with them (Akın, 2008). The reliability coefficient of the "Positive Relations with Others" sub-dimension was found .77 for its pretest and .78 for its posttest.

\section{Data Collection}

A preliminary study visit was made to Antalya Type-L Closed Penitentiary Institution after receiving permission from the Ministry of Justice, prior to the onset of main study and all the female inmates that will take part in the study were asked to sign an "Informed Consent Form", so as to obtain Ethics Committee Approval. In this context, a seminar was organized upon the permission of the prison management and the inmates were informed about the purpose and scope of the study both verbally and also in writing. At the end of the seminar, the volunteers, who were willing to participate in the study, were identified and the female inmates, who chose to participate in the exercises, were subjected to a questionnaire (PAR-Q) in order to determine whether they suffer from a health condition, or not. This process that lasted for 3 months is demonstrated in Figure 1. 
Köse, E., \& Yerlisu Lapa, T. (2020). The effect on the psychological perception of exercise in female inmates. Journal of Human Sciences, 17(2), 593-608. doi:10.14687/ihs.v17i2.5902

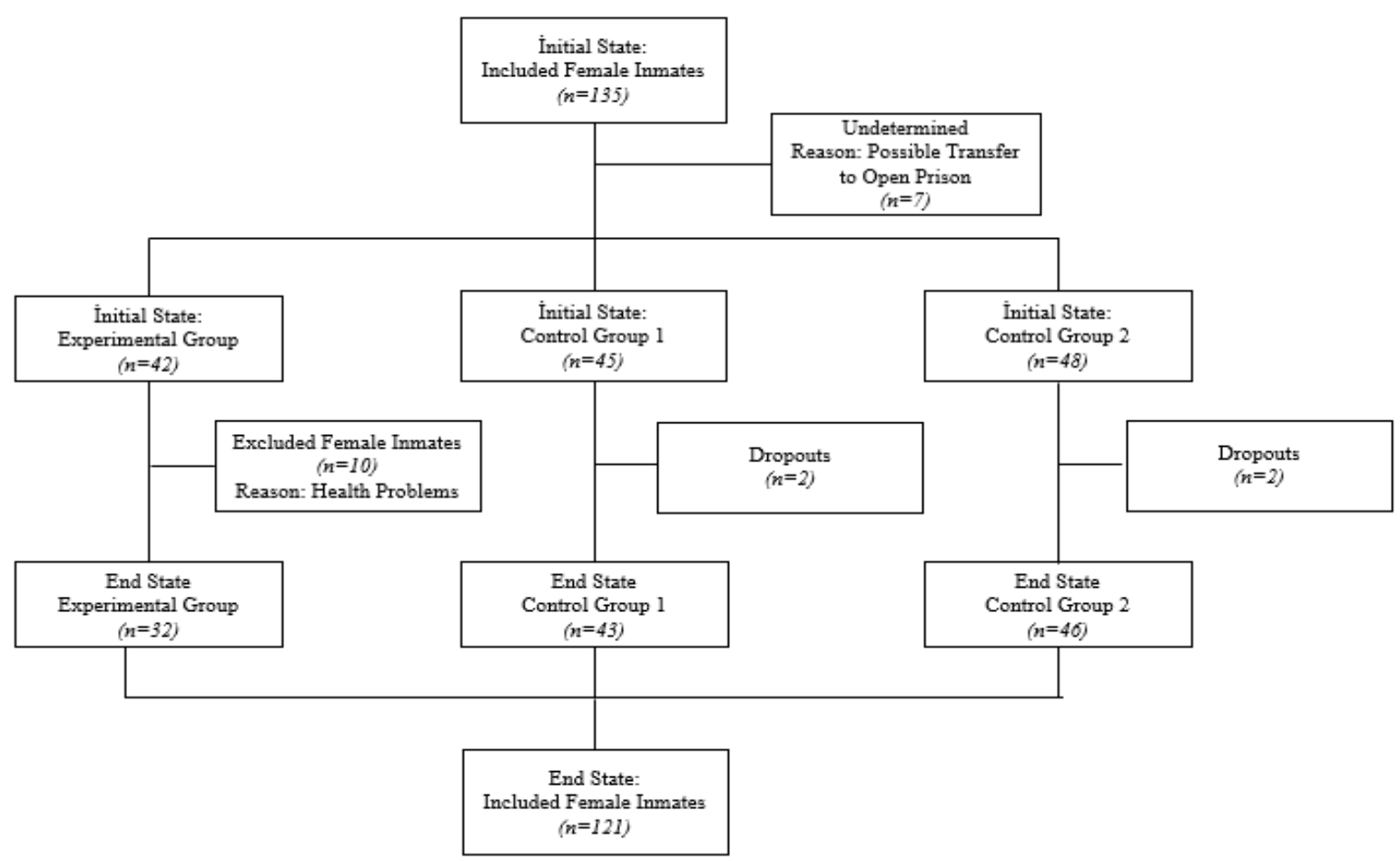

Figure 1: The Status of Inmates in the Study Process

The literacy status of the female inmates was determined during the pretest, which was applied before starting exercises and the researcher read all the scales one by one to 29 female inmates, who were classified as illiterate. The next stage of the study comprises of physical activities with recreational purposes. Due to the prison conditions and the lack of materials, basic level pilates class was replaced with volleyball class and the activity was transformed into a competition so as to make it more entertaining for the inmates. This physical activity with recreational purposes was carried out regularly and systematically for 3 days a week, 1 hour a day for 3 months by the researcher who graduated from the School of Physical Education and Sports and specialized in team sports. The first 20 minutes of the activity was spared for warm-up and stretching in order to prevent injuries.

\section{Data Analysis}

The data gathered via the Questionnaire was analyzed using SPSS 21 package software. In order to describe the personal characteristics of the female inmates and the demographic factors, descriptive statistical methods were utilized in the data analysis including frequency (n), percentage $(\%)$, arithmetic mean (Mean) and standard deviation (Sd). Fundamental assumptions regarding such analyses were assessed (dependent variable must be in the lowest interval scale and consistent, scores of the dependent variable must show normal distribution characteristics for each level of the between-groups factor and the difference scores must show a multivariate normal distribution in the universe) prior to the implementation of Dependent Groups t-Test and One-Way Analysis of Variance (ANOVA) for determining the impact of exercise on the psychological perception levels of the female inmates, such as depression, anxiety and psychological well-being. To this end, the normality distribution was tested in various ways. It was observed that the mode, median and arithmetic means of scores belonging to the dependent variable were close to each other, the histogram presented normal distribution and the kurtosis \& skewness values were between -1.5 to + 1.5. The fact that kurtosis $\&$ skewness values are between -1.5 to +1.5 indicates that the data presents normal distribution characteristics (Tabachnick \& Fidell, 2013). LSD Analysis, which is a Post-Hoc test, was carried out to determine among which groups there was a difference, following the statistically significant results of the One-Way Analysis of Variance. 
Köse, E., \& Yerlisu Lapa, T. (2020). The effect on the psychological perception of exercise in female inmates. Journal of Human Sciences, 17(2), 593-608. doi:10.14687/jhs.v17i2.5902

\section{Findings}

Table (2) presents the results of the One-Way Analysis of Variance (ANOVA) conducted for comparing scores of the psychological perception levels of the female inmates by participation groups before initiating the study.

Table 2

Pretest ANOVA Results of the Psychological Perception Levels by Distribution Groups

\begin{tabular}{llccccccc}
\hline & & $n$ & $\overline{\mathrm{X}}(s d)$ & $\begin{array}{c}\text { Sources of } \\
\text { Variance }\end{array}$ & $\begin{array}{c}\text { Sum of } \\
\text { Squares }\end{array}$ & df & $\begin{array}{c}\text { Mean } \\
\text { Squares }\end{array}$ & $\mathrm{F}$ \\
\hline \multirow{2}{*}{ Level of } & Exercise & 32 & $23.43 \pm 12.17$ & Between Groups & 2741.78 & 2 & 1370.89 & \\
Depression & Activity & 43 & $28.09 \pm 14.54$ & Within Groups & 21540.11 & 118 & 182.54 & $7.51^{*}$ \\
& None & 46 & $35.17 \pm 13.38$ & Total & 24281.90 & 120 & & \\
\hline \multirow{2}{*}{ Level of } & Exercise & 32 & $49.31 \pm 9.27$ & Between Groups & 1194.67 & 2 & 597.33 & \\
Anxiety & Activity & 43 & $51.16 \pm 7.90$ & Within Groups & 9176.84 & 118 & 77.77 & $7.68^{*}$ \\
& None & 46 & $56.67 \pm 9.29$ & Total & 10371.52 & 120 & & \\
\hline \multirow{2}{*}{$\begin{array}{l}\text { Psychological } \\
\text { Well-Being }\end{array}$} & Exercise & 32 & $59.84 \pm 12.32$ & Between Groups & 516.71 & 2 & 258.35 & \\
& Activity & 43 & $57.13 \pm 11.17$ & Within Groups & 15724.09 & 118 & 133.25 & 1.93 \\
& None & 46 & $54.63 \pm 11.32$ & Total & 16240.81 & 120 & & \\
\hline
\end{tabular}

$*(\mathrm{p}<.05)$

As per the participation groups, a statistically significant difference was found among the scores for the level of depression $(\mathrm{F}(2,118)=7.51 ; \mathrm{p}<.05)$ and the scores for the level of anxiety $(\mathrm{F}(2,118)=7.68 ; \mathrm{p}<.05)$, whereas no statistically significant difference was found among the scores of psychological well-being $(\mathrm{F}(2,118)=1.93 ; \mathrm{p}>.05)$.

According to the results of the LSD analysis, which is a Post-Hoc test, the depression and anxiety levels of the female inmates that participated in the exercises were lower than the ones who did not participate in any activity.

Table 3

Pretest-Posttest Assessments by Distribution Groups

\begin{tabular}{|c|c|c|c|c|c|}
\hline & & Pretest $\overline{\mathrm{X}}_{(s d)}$ & Posttest $\overline{\mathrm{X}}($ (sd) & $t$ & $p$ \\
\hline \multirow{3}{*}{ Participants of Exercise } & Depression & $23.43 \pm 12.17$ & $21.78 \pm 11.37$ & .79 & .433 \\
\hline & Anxiety & $49.31 \pm 9.27$ & $48.81 \pm 11.03$ & .38 & .706 \\
\hline & Psychological Well-Being & $59.84 \pm 12.32$ & $60.90 \pm 10.92$ & -.59 & .560 \\
\hline \multirow{3}{*}{ Participants of Activities } & Depression & $28.09 \pm 14.54$ & $28.74 \pm 14.26$ & -3.36 & $.002^{*}$ \\
\hline & Anxiety & $51.16 \pm 7.90$ & $52.06 \pm 7.99$ & -1.90 & .064 \\
\hline & Psychological Well-Being & $57.13 \pm 11.17$ & $56.23 \pm 10.68$ & 1.60 & .116 \\
\hline \multirow{3}{*}{ Non-Participation } & Depression & $35.17 \pm 13.38$ & $35.86 \pm 13.44$ & -2.55 & $.014^{*}$ \\
\hline & Anxiety & $56.67 \pm 9.29$ & $56.97 \pm 9.25$ & -1.59 & .119 \\
\hline & Psychological Well-Being & $54.63 \pm 11.32$ & $53.89 \pm 11.70$ & 1.71 & .093 \\
\hline
\end{tabular}

$*(\mathrm{p}<.05)$

Table (3) presents the averages of the total scores of pretest and posttest conducted to determine the psychological perception levels of the female inmates that participated in the exercise, before and after the study. Test results indicate that depression and anxiety levels of the female inmates participating in the exercise decrease and the psychological wellbeing scores increase. Although decreasing scores of the level of depression and anxiety as well as increasing scores of psychological well-being indicate a positive phenomenon; this change was not found to be at a 
Köse, E., \& Yerlisu Lapa, T. (2020). The effect on the psychological perception of exercise in female inmates. Journal of Human Sciences, 17(2), 593-608. doi:10.14687/ihs.v17i2.5902

significant level $(\mathrm{t}(45)=1.40 ; \mathrm{p}>.05 ; \mathrm{t}(45)=.79 ; \mathrm{p}>.05 ; \mathrm{t}(45)=.38 ; \mathrm{p}>.05 ; \mathrm{t}(45)=-.59 ; \mathrm{p}>.05)$. It is still safe to say that exercise has a positive effect on the psychological perceptions.

Analyzing the average scores among the psychological perception levels of the female inmates participating in the activities, it is observed that scores for the depression and anxiety levels increase and the scores for psychological well-being decrease. An increase on the scores for the depression and anxiety levels and a decrease on the scores for psychological well-being indicate a negative phenomenon. In this negative change, although the change regarding the anxiety and psychological well-being levels was not significant $(\mathrm{t}(45)=-1.90 ; \mathrm{p}>.05 ; \mathrm{t}(45)=1.60 ; \mathrm{p}>.05)$; the change on the level of depression was significant $(t(45)=-2.32 ; \mathrm{p}<.05 ; \mathrm{t}(45)=-1.90 ; \mathrm{p}<.05)$.

Analyzing the psychological perception levels of the female inmates, who did not participate in any of the activities, we see that the scores for the depression and anxiety levels increase, whereas the scores for psychological well-being decrease. Although this change regarding psychological perceptions is in a negative way, it is again significant for the level of depression $(\mathrm{t}(45)=-2.46 ; \mathrm{p}<.05$; $\mathrm{t}(45)=-2.55 ; \mathrm{p}<.05)$ but not significant for the levels of anxiety and psychological well-being $(\mathrm{t}(45)=1.59 ; \mathrm{p}>.05 ; \mathrm{t}(45)=1.71 ; \mathrm{p}>.05)$.

Table 4

ANOVA Results of the Posttest Scores of the Psychological Perception Levels by Participation Groups

\begin{tabular}{|c|c|c|c|c|c|c|c|c|}
\hline & & $n$ & $\overline{\mathrm{X}}(S d)$ & $\begin{array}{l}\text { Sources of } \\
\text { Variance }\end{array}$ & $\begin{array}{l}\text { Sum of } \\
\text { Squares }\end{array}$ & $\mathrm{df}$ & $\begin{array}{c}\text { Mean } \\
\text { Squares }\end{array}$ & $\mathrm{F}$ \\
\hline \multirow{3}{*}{$\begin{array}{l}\text { Level of } \\
\text { Depression }\end{array}$} & Exercise & 32 & $21.78 \pm 11.37$ & Between Groups & 3795.87 & 2 & 1897.93 & \multirow{3}{*}{$10.82^{*}$} \\
\hline & Activity & 43 & $28.74 \pm 14.26$ & Within Groups & 20692.87 & 118 & 175.36 & \\
\hline & None & 46 & $35.86 \pm 13.44$ & Total & 24488.74 & 120 & & \\
\hline \multirow{3}{*}{$\begin{array}{l}\text { Level of } \\
\text { Anxiety }\end{array}$} & Exercise & 32 & $48.81 \pm 11.03$ & Between Groups & 1325.68 & 2 & 662.84 & \multirow{3}{*}{$7.58^{*}$} \\
\hline & Activity & 43 & $52.06 \pm 7.99$ & Within Groups & 10316.64 & 118 & 87.42 & \\
\hline & None & 46 & $56.97 \pm 9.25$ & Total & 11642.33 & 120 & & \\
\hline \multirow{3}{*}{$\begin{array}{l}\text { Psychological } \\
\text { Well-Being }\end{array}$} & Exercise & 32 & $60.90 \pm 10.92$ & Between Groups & 936.65 & 2 & 468.32 & \multirow{3}{*}{$3.76 *$} \\
\hline & Activity & 43 & $56.23 \pm 10.68$ & Within Groups & 14664.85 & 118 & 124.27 & \\
\hline & None & 46 & $53.89 \pm 11.70$ & Total & 15601.50 & 120 & & \\
\hline
\end{tabular}

$*(\mathrm{p}<.05)$

Table (4) presents the results of the One-Way Analysis of Variance (ANOVA) conducted for comparing scores of psychological perception levels of the female inmates by participation groups, at the end of the study. The results indicate a statistically significant difference among the depression, anxiety and psychological well-being levels of the female inmates by participation groups $(\mathrm{F}(2,118)=10.90 ; \mathrm{p}<.05 ; \mathrm{F}(2,118)=10.82 ; \mathrm{p}<.05 ; \mathrm{F}(2,118) 7.58 ; \mathrm{p}<.05 ; \mathrm{F}(2,118)=3.76 ; \mathrm{p}<.05)$.

The results of the LSD analysis, which is a Post-Hoc test, reveal that the difference as for psychological well-being is in favor of the female inmates participating in the exercises compared to non-participating inmates. However, the difference as for the depression and anxiety levels is in favor of the exercise-participating and activity-participating inmates compared to non-participating inmates, respectively.

\section{Discussion and Conclusion}

Initially, we wanted to determine the reference psychological perception levels of the inmates according to their participation in recreational activities in prison. In this regard, the primary question of the researchers was whether psychological perception of the female inmates was an important factor for their decisions on the groups they choose to participate, or not. Therefore, the difference among the psychological perception of female inmates as per the participation groups was taken into consideration before initiating the study. The results of the study demonstrated that female 
Köse, E., \& Yerlisu Lapa, T. (2020). The effect on the psychological perception of exercise in female inmates. Journal of Human Sciences, 17(2), 593-608. doi:10.14687/ihs.v17i2.5902

inmates with higher psychological perception levels preferred to participate in collective activities such as exercise and their depression and anxiety levels were lower compared to other inmates. At this point, it is possible to claim that depression and anxiety levels were deterministic regarding their participation in exercise or non-participation in any activity. In other words, one can say that if an inmate has high level of depression or anxiety, she prefers to spend all her time in the ward, instead of participating in any activity. Although we observe that psychological well-being level of the inmates, who participated in exercises, was higher compared to other groups (those who only participates in the activities and those who did not participate in anything), such difference is not at a significant level. In this context, we can say that psychological well-being level is not a determinant for involvement in any of the groups. Reviewing the literature with regards to the findings of the study, we see that mood is a significant determinant for participating in any activity (Lewinsohn \& Graf, 1973). Another important psychological perception that affects the mood of the inmates is depression. The studies show that depressed people are less interested in the entertaining leisure activities and they have difficulty in participating in any activity (Blanko \& Barnett, 2014). The number of studies focusing on the relationship between participation of elderly and disabled individuals, which are considered to be disadvantaged groups such as imprisoned individuals, in leisure activities and their psychological perceptions is considerably high and their results show similarity (Dupuis \& Smale, 1995; Holtfreter, Reisig \& Turanovic, 2015; Ouyang, Chong, Kin \& Liu, 2015). The results of numerous studies share similar findings and they demonstrate that there is a negative correlation between leisure activity participation and negative psychological perceptions such as depression and anxiety. Moreover, increasing level of anxiety has a negative impact on the motivation, which is regarded as one of the psychological perceptions affecting leisure participation (Kaufman, 1988). Another psychological perception, which is important for leisure activity participation and influenced by the increased level of anxiety, is leisure satisfaction. In another saying, the higher the anxiety level of an individual; the less they find pleasure or satisfaction in participation in any recreational activity. Accordingly, it is understandable to find that people, who participate in the leisure-time physical activities, have lower level of anxiety and depression compared to people, who do not participate in any type of activity, when we evaluate the studies in the literature in the context of female inmates. Therefore, the results of this study show parallelism with the results of other studies in the literature, since they indicate that individuals with high psychological perception levels have a higher tendency of participating in the leisure activities.

The results of the analysis conducted to demonstrate the effects of exercise on the psychological perceptions and to detect the change on the psychological perceptions subsequent to regular and systematic exercise were the following: the pre- and post-exercise depression levels of the female inmates, who participated in the exercises, were lower after the exercise, although the difference was not statistically significant. Many studies in the literature establish that exercise creates a positive change on the psychological perceptions and this change is significant. Another study conducted in 2004 tried to detect the effect of exercise on anxiety, depression and self-esteem. In this connection, female students were divided into experimental and control groups in a study in Korea and the psychological outcomes of the exercising group were compared to the results of the girls in the control group. The results indicated that anxiety and depression levels of exercising individuals decreased, whereas their self-esteem levels increased (Kim, Cohen, Oh, \& Sok, 2004). Many other studies also concentrated on the positive effects of regular exercise on depression and revealed that exercise makes a significant difference on depression. For example; the results of a research, which reviewed various meta-analyses for identifying the effects of exercise on depression, indicated that exercise can help prevent the onset or recurrence of depression (Andersson, Hovland, Kjellman, Taube \& Martinsen, 2014). Another study established that exercise is as efficient as medication in the treatment of people with mild to moderate level of depression and it improves the symptoms of depression, when used in combination with drug therapy (Carek, Laibstain \& Carek, 2011). It appears that exercise decreases the depression level of incarcerated individuals, however; the reason why the difference is not significant is another topic that needs to be discussed and tackled, separately. 
Köse, E., \& Yerlisu Lapa, T. (2020). The effect on the psychological perception of exercise in female inmates. Journal of Human Sciences, 17(2), 593-608. doi:10.14687/ihs.v17i2.5902

Anxiety is another parameter on which the effect of exercise is also researched about. The difference between the results of pretest and posttest carried out to detect the change on the anxiety level is in favor of the posttest, although it is not statistically significant. The averages for the anxiety level of the experimental group decreased after participating in the exercises. The decrease of the anxiety scores indicates that anxiety also improves. On that sense, anxiety results show resemblance to the results related to depression levels. Other studies in the literature also show that exercise lowers the anxiety level and affect individuals, positively (Dunn, Trivedi \& O'Neal, 2001; Wyshak, 2001). One of the reviews in the literature analyzing the relationship between exercise and anxiety revealed that moderate-level aerobic exercises lower the anxiety level, when performed at least twice a week, for 9 weeks (Wang, Ku, Lin, Ratey \& Chang, 2014).

The psychological well-being results also show parallelism to the other two parameters. Psychological well-being levels of the inmates, who exercised regularly, were found to be increasing, however; the change was not significant. Reviewing the physical activity-related studies, we see that exercise and physical activity decrease the prevalence of negative affect but increase the positive affect and psychological well-being, accordingly (Ströhle et al., 2014). Studies in the literature assert that exercise effects the psychological well-being level of people and generally this impact is both positive and significant.

As mentioned in the beginning of the discussion, our study reveals that all results regarding the psychological perceptions indicate a positive change in the experimental group, but the level of this change is not significant. All the other factors that might affect the psychological perceptions of the inmates should be assessed and the conditions they live under should be brought into view, in order to make a sound comment on this matter. However, there is only a limited number of inmateoriented studies in the national and international literature, which limits the comments one can make on this matter. Even so, one can say that there are numerous factors that affect the psychological perception of the inmates, negatively, within the scope of the knowledge we drive from the limited studies we can find. The most important of them is the psychological destruction that comes along with imprisonment. Moreover, it is stated that the majority of these inmates do not possess even a minimum level of education, professional experience or the financial support they need to maintain their lives; many have broken families and they are excluded from their social circles and the society, after being involved in crime. The current situation is blindingly obvious in the study of Soytürk (2013), where she dwells upon the social services needs of the convicts and detainees. The study reveals that $27.5 \%$ of the convicts were unemployed before imprisonment and this out-of-job period was longer than 98 months in average; the monthly income that the convicts had before imprisonment, if any, was lower than minimum wage and they had no social security; plus, $23 \%$ of them had chronic health problems before imprisonment, who mostly also had psychiatric problems. Besides, it is indicated that $20 \%$ of these convicts were being treated for psychiatric conditions before imprisonment and the underlying reason behind such conditions was depression.

From an economic point of view, it is ascertained that $58.6 \%$ of the convicts did not have the financial means to meet their needs in prison, $94.1 \%$ lived on in kind/in cash aids, provided by the social welfare institutions. In addition to all these, $13.1 \%$ of the convicts became acquainted with a new substance in prison and developed addiction. Although not many, some of them had some unsettling stories such as having a child or an elderly parent or a disabled relative residing in a social institution. In addition to all this information, many of the convicts will have no job after being released from prison and they are concerned that they will experience post-release adaptation problems with their spouses, children and families (Soytürk, 2013). During the course of our study, the researcher had conversations with the convicts and the notes taken by the researcher on the field were also consistent with the above-mentioned issues. However, qualitative field notes were not included in the study, since this study was designed as an experimental study within the scope of positivist paradigm research. Another study conducted by the same researcher on convicts with past prison experience at the Directorate of Probation also revealed similar results, supporting all these findings. In a similar manner, the results of Köse's study (2018) that concentrated on the physical 
Köse, E., \& Yerlisu Lapa, T. (2020). The effect on the psychological perception of exercise in female inmates. Journal of Human Sciences, 17(2), 593-608. doi:10.14687/ihs.v17i2.5902

activity constraints faced by the criminals demonstrated that majority of these individuals express that they cannot find a job, they are socially excluded, they have family members under their care due to broken family structures and they experience psychological breakdown. In the light of this information, it would not be wrong to say that regular physical activity alone is not sufficient for the improvement of the psychological perception of such inmates; in addition to that, primary concerns of these people such as survival and social adaptation along with some other needs such as education, employment and equality also play a significant role on their psychological perceptions.

Reviewing the change on the psychological perceptions of the group that participated in the activities, it was observed that participation in any activity did not have a positive impact on the level of depression. The studies carried out on this group revealed that the level of depression increased, even significantly. Anxiety level on the other hand, which is another variable, showed no decrease but it increased, although not significantly. Finally looking at the psychological well-being level of the activity-participating group, again we see that psychological well-being levels did not improve but they further lowered, although not significantly.

The last group of the study to be assessed is the group of inmates, who did not participate in any of the activities, whatsoever. It was found that those inmates, who did not participate in any of the activities or events organized by the prison management, had increasing level of depression and the change was at a significant level. It was also observed that the averages of their anxiety level showed a slight increase, while psychological well-being levels demonstrated a decrease. However, the negative effect on these last two parameters was not significant.

The study revealed that elapsed time did not create any positive change on the control groups; neither on those who participated in the activities nor on those who did not participate in anything. As a matter of fact, psychological perceptions were observed to be worsening as time passed by, which was believed to be resulting from the problems brought by prison life and incarceration in general. Bendseson's study conducted on inmates in Sweden also concluded similar results and showed that the longer the time spent as an inmate, the higher the chances of remaining one. (Cit. Adler, Mueller, \& Laufer, 2006: 49) Besides, it is stated that individuals with longer imprisonment time are inclined to become repeat offenders and they gain a more criminal identity (Kury, Ferdinand \& Obergfell-Fuchs, 2003; Livingston, 1998: 503-504). It is important to assess the needs of the inmates more thoroughly so as to understand the negative effects of incarceration on the inmates and have a more efficient discussion. In this regard, the study of Sykes, which was also carried out on inmates, can shed a light on the findings of our research. In Syke's opinion (1958: 447445), imprisonment life can cause some deprivations for the individuals. The first of those is the deprivation of liberty. Individuals, who are deprived of their liberty, are also deprived of their families, friends and loved ones. This situation leads to isolation and loneliness, which causes those individuals to estrange from emotional relationships. Additionally, individuals, who are deprived of heterosexual relationships, are deprived of meeting some of their sexual needs, as well and severe psychological problems can occur, if the duration of deprivation is longer. Another type of deprivation is deprivation of personal security. Lack of personal security can cause violence and abuse on some inmates inflicted by other inmates. Apart from these, they are deprived of autonomy and the ability to acquire wealth and property due to the fact that the authorities regulate the whole imprisonment process. It is noted that they are also deprived of goods and services. It is observed that deprivation and restriction have negative effects on the psychology and attitude of the inmates and with increased length of sentence, such effects are believed to escalade. Considering that above-mentioned information is in parallel with the findings of our research, we can better understand why imprisonment affects psychological perceptions, negatively (Barlow, Barlow \& Chiricos, 1993).

The last finding of the research contains the comparison of female inmates according to the participation groups, at the end of the study. Comparison of psychological well-being scores of female inmates demonstrates statistically significant difference among the participation groups. This difference is between the those who participated in the exercises and those who did not agree to attend anything. Evaluating the anxiety and depression levels of the female inmates, again we see 
Köse, E., \& Yerlisu Lapa, T. (2020). The effect on the psychological perception of exercise in female inmates. Journal of Human Sciences, 17(2), 593-608. doi:10.14687/ihs.v17i2.5902

difference from one participation group to another and such difference was found to be in favor of those who participated in exercises and activities at a significant level.

The psychological perception levels of the incarcerated individuals can play a determining role on how they spend their time in prison. While individuals at a better psychological state more actively attend the activities, seminars and self-improvement courses organized by the prison management; individuals with lower psychological perception level undergo their incarceration rather passively. At this point, it is possible to say that psychological perceptions have an impact on the participation group and at the same time the form of participation affects the perceptions. More clearly, inmates with higher psychological perception levels chose to participate in the exercises and the psychological perception level of those who exercised regularly for three months also improved. In other words, psychological perception levels not only affected the preferences of the individuals but they, too, were affected by the exercise itself. These results also revealed that participation in physical activities yield more positive outcomes for the psychological perceptions, compared to other social activities. Although exercise-participating individuals presented better psychological perception levels compared to other groups, it should not be overlooked that regular exercise did not create a significant change. Considering the challenges of incarceration, we see that there are many variables that can affect the psychological perceptions, negatively. Therefore, the results are understandable. The fact that positive change on the psychological perceptions of those who exercised was not at a significant level should not be assessed as a negative outcome. While the time spent as an inmate gradually give birth to negative results on individuals, it is thought that exercise has a protective role over psychological perceptions, and this has a significant impact on the quality of life of the inmates. However, we need other research designs, in which confounding factors can be manipulated, in order to reveal the true effect of exercise on the psychological perceptions. Additionally, exercise should be assessed not only for its effect on psychological perceptions but also on the physical parameters. This way it would be possible to comment on how physical factors are also indicative of psychological perceptions.

In conclusion, psychological perceptions of those who participated in recreational activities and those who did not participated in any activity changed negatively in time, whereas psychological perceptions of those who participated in the exercises manifested no negative change. Based on this result, it can be said that exercise plays an important role in protecting psychological health.

\section{References}

Adler, F., Mueller, G.O., \& Laufer, W. S. (2006). Criminal justice. (4th ed.) New York: McGraw-Hill Education.

Akın, A. (2008). The scales of psychological well-being: A study of validity and reliability. Educational Sciences: Theory and Practice, 8(3), 741-750.

Amtmann, J., Evans, R., \& Powers, J. (2001). Measured and perceived effects of a correctional wellness program. Corrections Compendium, 26(9), 1-6. Retrieved from http://www.aca.org/publications/ccjournal.asp.

Andersson, E., Hovland, A., Kjellman, B., Taube, J., \& Martinsen., E. (2014). Physical activity is just as good as CBT or drugs for depression. Lakartidningen, 112.

Artal, M., Sherman, C., \& Dinubile, N.A. (1998). Exercise against depression. The Physician and Sportsmedicine, 26(10), 55-60.

Barlow, D.E., Barlow, M.H., \& Chiricos, T.G. (1993). Long economic cycles and the criminal justice system in the U.S. Crime, Law and Social Change, 19(2), 143-169.

Başaran, Z. (2015). 12 haftalık rekreatif etkinliklerin kadın hükümlülerin sürekli kayg1 düzeyine etkisi. International Journal of Science Culture and Sport, Special Issue 3, 561-574.

Bellack, A.S., Hersen, M., \& Himmelhoc, J. (1981). Social skills training compared with pharmacotherapy and psychotherapy in the treatment of unipolar depression. American Journal of Psychiatry, 138(12), 1562-1567. 
Köse, E., \& Yerlisu Lapa, T. (2020). The effect on the psychological perception of exercise in female inmates. Journal of Human Sciences, 17(2), 593-608. doi:10.14687/ihs.v17i2.5902

Blanko, A.J., \& Barnett, L.A. (2014). The effects of depression on leisure: varying relationships between enjoyment, sociability, participation, and desired outcomes in college students. Leisure Sciences, 36(5), 458-478.

Buckaloo, B. J., Krug, K. S., \& Nelson, K. B. (2009). Exercise and the low-security inmate: Changes in depression, stress, and anxiety. The Prison Journal, 89(3), 328-343.

Büyüköztürk, Ş., Çakmak, E.K., Akgün, Ö.E., Karadeniz, Ş., \& Demirel, F. (2014). Bilimsel arastırma yöntemleri. Ankara: Pegem Akademi Yayınları.

Callaghan, P. (2004). Exercise: A neglected intervention in mental health care. Journal of Psychiatric and Mental Health Nursing, 11(4), 476-483.

Carek, P.J., Laibstain, S.E., \& Carek, S.M. (2011). Exercise for the treatment of depression and anxiety. The International Journal of Psychiatry in Medicine, 41(1), 15-28.

Dunn, A.L., Trivedi, M.H., \& O'Neal, H.A. (2001). Physical activity dose-response effects on outcomes of depression and anxiety. Medicine \& Science in Sports \& Exercise, 33(6), 587-597.

Dupuis, S.L., \& Smale, B.J.A. (1995). An examination of relationship between psychological wellbeing and depression and leisure activity participation among older adults. Society and Leisure, 18(1), 67-92.

Edwards, S. (2006). Physical exercise and psychological well-being. South African Journal of Psychology, 36(2), 357-373.

Elger, B. (2009), 'Prison life: Television, sports, work, stress and insomnia in a remand prison. International Journal of Law and Psychiatry, 32, 74-83.

Engels, H.-J., Currie, J., Lueck, C., \& Wirth, J. (2002). Bench/step training with and without extremity loading: Effect on muscular fitness, body composition profile, and psychological affect. Journal of Sports Medicine and Physical Fitness, 42(1), 71-78.

Fagard, R.H., \& Cornelissen, V.A. (2007). Effect of exercise on blood pressure control in hypertensive. European Journal of Cardiovascular Prevention and Rehabilitation, 14, 12-17.

Fazel, S., Hope, T., O'Donnell, I., Piper, M., \& Jacoby, R. (2001). Health of elderly male prisoners: Worse than the general population, worse than younger prisoners. Age and Ageing, 30(5), 403407.

Folkins, C.H., \& Sime, E.W. (1981). Physical fitness training and mental health. American Psychologist, 36(4), 373- 389.

Fraenkel, J.R., \& Wallen, N.E. (2006). How to design and evaluate research in education (6th ed.). New York, NY: McGraw-Hill.

Frank, J., Adkins, A., Thomas, N., \& Dick, D. (2016). The relationship between exercise and depression and anxiety in college students. Virginia Commenwealth University.

Frey, J. H., \& Delaney, T. (1996). The role of leisure participation in prison. Journal of Offender Rehabilitation, 23(1-2), 79-89.

Galper, D.I., Trivedi, M.H., C.E., Dunn, A.L., \& Kampert, J.B. (2006). Inverse association between physical inactivity and mental health in men and women. Medicine and Science in Sports and Exercise, 38(1), 173-178.

Geçtan, E. (2005). Psikanaliz ve sonrası. İstanbul: Metis Yayınları.

Güçlü, M.B., Sağlam, M., İnce, D.İ., Savc1, S., \& Arıkan, H. (2008). Hipertansiyon ve egzersiz. Ankara: Klasmat Yayıncilik.

Hefferon, K., \& Boniwell, I. (2011). Positive psychology: Theory, research and applications. New York: McGraw Hill Education (UK).

Hills, A.R., Dengel, D., \& Lubans, D.R. (2015). Supporting public health priorities: recommendations for physical education and physical activity promotion in schools. Progress in Cardiovascular Diseases, 57, 368-374.

Hisli, N. (1989). Beck depresyon envanterinin üniversite öğrencileri için geçerliği, güvenirliği. Psikoloji Dergisi, 7(23), 3-13. 
Köse, E., \& Yerlisu Lapa, T. (2020). The effect on the psychological perception of exercise in female inmates. Journal of Human Sciences, 17(2), 593-608. doi:10.14687/ihs.v17i2.5902

Holtfreter, K., Reisig, M.D., \& Turanovic, J.J. (2017). Depression and infrequent participation in social activities among older adults: The moderating role of high-quality familial ties. Aging \& Mental Health, 21(4), 379- 388.

İnce, M.L., \& Ebem, Z. (2009). Role of exercise stages in self-reported health-promoting behaviors of a group of Turkish adolescents at transition to university. Perceptual and Motor Skills, 108(2), 399-404.

Kaufman, J.E. (1988). Leisure and anxiety: A study of retirees. Activities, Adaptation \& Aging, 11(1), 110.

Kamijo, K., Hayashi, Y., Sakai, T., Yahiro, T., Tanaka, K., \& Nishihira, Y. (2009). Acute effects of aerobic exercise on cognitive function in older adults. Journal of Gerontology: Psychological Sciences, 64B(3), 356-363.

Kautiainen, S., Koivusilta, L., Lintonen, T., Virtanen, S., \& Rimpelä, A. (2005). Use of information and communication technology and prevalence of overweight and obesity among. International Journal of Obesity, 29, 925-933.

Kaya, A., Gedik, V. T., Bayram, F., \& Bahçeci, M. (2011). Oberite, dislipidemi, hipertansiyon hekim için tan ve tedavi rehberi. Ankara: Miki Matbaacilik.

Kaya, N., Güler, Ö., \& Çilli, A.S. (2004). Konya kapalı cezaevi'ndeki mahkumlarda psikiyatrik bozuklukların yaygınlı̆̆. Anadolu Psikiyatri Dergisi, 5(2), 85-91.

Kendler, K.S., Karkowski, L M., \& Prescott, C.A. (1999). Causal relationship between stressful life events and the onset of major depression. American Journal of Psychiatry, 156(6), 837-841.

Keyes, L.C., Shmotkin, \& Ryff, C.D. (2002). Optimizing well-being: The empirical encounter of two traditions. Journal of Personality and Social Psychology, 82(6), 1007-1022.

Kim, K.B., Cohen, S., Oh, H.K., \& Sok, S. (2004). The effects of meridian exercise on anxiety, depression, and self-esteem of female college students in Korea. Holistic Nursing Practice, 18(5), 230-234.

Köknel, Ö. (2005). Kişilik, kaygıdan mutlulŭga. İstanbul: Altın Kitaplar Yayınevi.

Köse, E., \& Yerlisu Lapa, T. (2018). Individuals who benefited from Probation: Leisure Time Physical Activity Constraints, International Recreation and Sports Management Congress. (pp.269-270). Muğla-Antalya.

Kury, H., Ferdinand, T.N., \& Obergfell-Fuchs, J. (2003). Does severe punishment mean less criminality? International Criminal Justice Review, 13(1), 110-148.

Leberman, S. (2007). Voices behind the walls: Female offenders and experiential learning. Journal of Adventure Education \& Outdoor Learning, 7, 113-120.

Lewinsohn, P.M., \& Graf, M. (1973). Pleasant activities and depression. Journal of Consulting and Clinical Psychology, 41(2), 261-268.

Livingston, M. (1997). A review of the literature on self-injurious behavior amongst prisoners. Issues in Criminological \& Legal Psychology, 28, 21-35.

Oner, N., \& Le Compte, A. (1983). Durumluk - sürekli kaygı envanteri el kitabı. Boğaziçi Üniversitesi Yayını, İstanbul.

Ouyang, Z., Alice, M.L., Kin C.T., \& Liu, S. (2015). Leisure, functional disability and depression among older Chinese living in residential care homes. Aging \& Mental Health, 19(8), 723-730.

Ozano, K.A. (2008). The role of physical education, sport and exercise in a female prison (Doctoral dissertation) Retrieved from http://hdl.handle.net/10034/84838.

Özalp, H., \& Algün, C. (2013). Mahkûm ve mahkûm olmayan 60 yaş üzeri erkeklerde denge ve fiziksel performansin karşılaştırlması. Fiæ̧yoterapi Rehabilitasyon, 24(1), 47-53.

Pérez-Moreno, F., Cámara-Sánchez, M.,Tremblay, J.F., Riera-Rubio, V.J., Gil-Paisán, L., \& Lucia, A. (2007). Benefits of exercise training in Spanish prison inmates. International Journal of Sports Medicine, 28(12), 1046-1052.

Plummer, D. (2004). Helping Adolescents and adults to build self-esteem: A photocopiable resource book. Jessica Kingsley Publishers, London. 

Human Sciences, 17(2), 593-608. doi:10.14687/ihs.v17i2.5902

Püllüm, E. (2011). Mahkum kadınların yaşam kalitesi ve denge düzeylerinin değerlendirilmesi. İzmir: Sağlık Bilimleri Enstitüsü, Dokuz Eylül Üniversitesi.

Ryff, C. D. (1989a). Happiness is everything or is it? Explorations on the meaning of psychological well-being. Journal of Personality and Social Psychology, 57(6), 1069-1081.

Ryff, C. D. (1989c). Beyond ponce de Leon and life satisfaction: New directions in quest of successful aging. International Journal of Behavioral Development, 12(1), 33-55.

Ryff, C. D., \& Keyes, C. L. (1995). The structure of psychological well-being revisited. Journal of Personality and Social Psychology, 69(4), 719-727.

Ryff, C. D., \& Singer, B. (1996). Psychological well-being: meaning, measurement, and implications for psychotherapy research. Psychotherapy and psychosomatics, 65(1), 14-23.

Soytürk, S. (2013). Hükümlü ve tutukluların sosyal hizmet gereksinimlerinin değerlendirilmesi: karaman m tipi kapalı-açık cezaevi örneği. Yayımlanmamış yüksek lisans tezi, Hacettepe Üniversitesi, Sosyal Bilimler Enstitüsü.

Soyuer, F., \& Soyuer, A. (2008). Yaşll1ık ve Fiziksel aktivite. İnonü Üniversitesi Trp Fakültesi Dergisi, 15(3), 219-224.

Spielberger, C. D., Gorsuch, L. R., \& Lushene, R. (1970). Manual for the State-Trait Anxiety inventory. Palo Alto, CA: Consulting Psychologists Press.

Stephan, Y., Sutin, A. R., \& Terracciano, A. (2014). Physical activity and personality development across adulthood and old age: Evidence from two longitudinal studies. Journal of Research in Personality, 49, 1-7.

Ströhle, A., Feller, C., Onken, M., Godemann, F., Heinz, A., \& Dimeo, F. (2014). The acute antipanic activity of aerobic exercise. The American Journal Psychiatry, 162(12), 2376-2378.

Sümer, N., \& Güngör, D. (1999). Çocuk yetistirme stillerinin baglanma stilleri. Türk Psikoloji Dergisi, 14(44), 35-58.

Sykes, G. M. (1958). The society of captives. Princeton, NJ: Princeton University Press.

Tabachnick, B.G., \& Fidell, L.S. (2013). Using multivariate statistics (6th ed.), Boston: Allyn and Bacon.

Vaiciulis, V., Kavaliauskas, S., \& Radisauskas, R. (2011). Inmates' physical activity as part of the health ecology. Open Medicine, 6(5), 679-684.

Wang, C. C., Ku, P. W., Lin, C. Y., Ratey, J. J., \& Chang, Y. K. (2014). An overview of the relationship between exercise and anxiety disorders. Airitilibrary, 14(1), 51-70.

Wagner, M., McBride, R. E., \& Crouse, S. F. (1999). The effects of weight-training exercise on aggression variables in adult male inmates. The Prison Journal, 79(1), 72-89.

Windle, G., Hughes, D., Linck, P., Russell, I., \& Woods, B. (2010). Is exercise effective in promoting mental well-being in older age? A systematic review. Aging \& Mental Health, 14(6), 652-669.

Wolf, A. M., \& Colditz, G. A. (1998). Current estimates of the economic cost of obesity in the United States. Obesity, 6(2), 97-106.

Wyshak, G. (2001). Women's college physical activity and self-reports of physician diagnosed depression and of current symptoms of psychiatric distress. Journal of Women's Health \& Gender-Based Medicine, 10(4), 363-370. 